\title{
Deepening democracy within Ireland's social partnership
}

\author{
Niamh Gaynor \\ Academic Theme Leader's Office \\ Dublin City University \\ Glasnevin \\ Dublin 9 \\ T: $+353(0) 17005637$ \\ M: +353 (0)871258713 \\ E: niamh.gaynor@dcu.ie
}

\begin{abstract}
:
Ireland's social partnership process, now under attack from a number of quarters, has repeatedly been charged with being 'undemocratic' in that it undermines the sovereign position of elected political representatives, with key policy formulation and decision-making taking place in fora outside the institutions of representative democracy. These critiques echo those against new forms of networked governance more globally. A key question therefore is how (and if) democracy may be deepened within social partnership or its potential successor(s). This article addresses this question by employing a post-liberal democratic framework to examine social partnership in practice, and by drawing lessons from another partnership process, Malawi's PRSP. Drawing from Malawi's experience, it is argued that democracy can be deepened within social partnership when governance deliberations and negotiations are conducted under conditions of vibrant public debate and genuine perspective-based representation, and when the communicative and discursive norms are widened to allow for such representation.
\end{abstract}




\section{Introduction}

At a time when some of the world's most visible wars are played out in the name of democracy, charges of governance systems being 'undemocratic' have acquired a particular potency. Such a charge has repeatedly been made against Ireland's social partnership process, both at an academic level (Ó Cinnéide, 1999, 2006), and more popularly, among actors from across the political spectrum (see for example Fine Gael and Labour's concerns about Social Partnership's 'democratic deficit' (www.finegael.ie), Charlie McCreevy's trenchant criticisms quoted in Hastings, Sheehan and Yeates (2007), and ISME's charges (The Irish Times, 2007)). The principal cause of concern is that social partnership undermines the sovereign position of elected political representatives with key policy formulation and decision-making taking place in fora outside the institutions of representative democracy.

These critiques echo charges against recent, more participatory forms of governance more globally. Viewed through a more global lens, Ireland's social partnership is not unique. Since the 1990s, governance across a wide range of states, in the global North and South alike, has come to be characterised by states networking with a range of actors that cut across private and social spheres. Variously described as participatory governance (Newman, 2005), multi-governance (Bang, 2004), joined-up governance (Reddel, 2004), co-governance (Kooiman, 2003, Dean, 2007) or, after Castells' (2004) 'network state', network governance (Bogason and Musso, 2006, Triantafillou, 2004), within such arrangements the role of the state is described as shifting from that of 'governing' through direct forms of control, to that of 'governance', in which it collaborates with a wide range of civil actors in networks that cut across the public, private and voluntary sectors, and operate across different levels of decision-making. The Poverty Reduction Strategy Process (PRSP), a national partnership process bringing together a range of state and civic actors in policy deliberation, and institutionalised in over seventy countries worldwide comprising around one third of the world's population (IMF/World Bank, 2002), is another example of such new forms of governance ${ }^{1}$. As with social partnership, one of the core concerns of commentators observing these diverse processes across the globe is the question of whether these deepen or undermine democracy within their member states (see 
Bobbio, 1987, Pierre, 2000, Held and McGrew, 2003 on governance more broadly; Cornwall and Brock, 2005, Weber, 2006 on PRSPs specifically).

Such concerns are significant given the growing ubiquity of partnership arrangements both locally and nationally in countries throughout the world. While, in Ireland, it is now unclear if social partnership will survive within the current challenging economic climate, it is highly likely that the governance ethos and mechanisms which underpin it will continue in some form or other (for instance see Murphy and Hogan 2008 on the predecessor to the current social partnership model). As Sorensen and Torfing, surveying the European political spectrum, assert, 'network politics is here to stay' (2005: 198). In this context, whatever the future configurations of governance in Ireland, an ongoing concern will be how democratic or otherwise they prove and, more particularly, how democracy might be deepened within and through them.

With this in mind, this paper employs a post-liberal democratic framework, with specific reference to the work of Iris Marion Young (2000), to examine how democracy might be deepened within Ireland's social partnership, affording a voice to greater numbers of citizens in determining the developmental direction of the country in years to come. Employing a framework drawn from the work of Young, lessons are drawn from another partnership process, Malawi's PRSP, to elicit some conditions for deepening democracy within the process. Malawi's first PRSP strategy - a three year strategy - was formulated in 2000/2001 and launched in 2002. Its second strategy, known as the Malawi Growth and Development Strategy (MGDS) - a five year strategy - was formulated in 2005/2006 and launched in 2007. While Malawi's PRSP, embedded in a country which clearly differs significantly in economic, social, political and cultural terms might seem an unlikely source of lessons for social partnership in Ireland, in a globalised world of starkly similar governance arrangements (both social partnership and Malawi's PRSP are national development strategy processes; both are underpinned by concepts of partnership, participation and good governance; both involve a range of civic actors; and both result in consensusbased agreements) these contextual differences prove the very source of such lessons. The principal lesson from Malawi's process is that political culture plays a key role. More specifically, we learn from Malawi's process that democracy can be deepened when governance deliberations and negotiations are conducted under conditions of 
vibrant public debate and genuine perspective-based representation and when the communicative and discursive norms are widened to allow for such representation. The findings presented below also show that contrarily, under conditions of muted public debate engendered by norms of confidentiality such as those imbuing Ireland's social partnership, where negotiations and deliberations take place within invisible spaces, and where the likelihood of 'mis-framing' of constituents' issues and analyses is increased, democracy is not deepened, rather it is diluted and undermined.

\section{Theorising Social Partnership: Liberal and post-liberal democratic theories}

While critics of social partnership who charge it with being 'undemocratic' do not explicitly outline their understanding of what, in their view, constitutes a 'democratic' process, their persistent references to the sidelining of national parliament and elected public officials implicitly suggests that their comments come from the standpoint of liberal democratic theory, with its attendant emphasis on institutions of representative democracy. Deriving from the development of liberalism, and linked to the idea of individual rights, contemporary liberal democratic theory focuses on the rights of citizens to freely choose their rulers at periodic intervals (Manin, 1997). Whether from the perspective of its aggregative or integrative strands ${ }^{2}$, this body of theory places considerable emphasis on the formal institutions of representative democracy. Within the state, power between the citizens and the state is balanced on election day when voters elect political leaders (Macpherson, 1977). Equality is thus attained through the 'one citizen, one vote' process, thereby assuring an equal influence on leadership selection.

Following liberal theory therefore, governance arrangements such as those provided for by social partnership may indeed be seen, as its detractors contend, to undermine liberal democracy in a number of ways. First, they undermine the equality of access posited by the liberal model by creating separate channels of political influence with differential access for select social actors. Second, their restricted transparency undermines the ability of citizens to make informed political choices. Third, the delegation of decision-making powers to specific governance actors (social partners and public/civil servants) undermines the ability of elected representatives to control 
political processes and outcomes. And fourth, the influence of transnational actors within contemporary governance arrangements (in the form of the invisible, yet significant influence of international capital) transcends the nationally delineated boundaries posited by traditional liberal democratic theory.

However, the liberal democratic image of politics as an activity proceeding exclusively through the national parliament is, in contemporary times, questionable. As we are well aware, both before and after elected leaders pass a particular bill, or instruct public administrators to take certain action, crucial decisions are made within complex policy networks (both national and international) that set the political agenda, frame and define the policy problems, and craft and implement the appropriate solutions. Taking the reality of such governance arrangements as a starting point, the question therefore becomes how (and indeed if) democracy might be deepened through and within such arrangements. This question has been the focus of theoretical work by Sorensen and Torfing (2005) who argue that post-liberal democratic theory proves more useful in examining contemporary governance processes. Drawing on this theoretical work and focusing in particular on post-liberal theories which measure the democratic quality of governance by its ability to produce just and equitable outcomes, this article examines how democracy can be deepened within social partnership. The use of a theoretical framework focused on equity of outcome, I believe, proves particularly apt to the Irish situation given the growing inequalities that characterised the so-called 'Celtic Tiger' boom period (Kirby, 2004, NESC, 2005; see also Kelly, McGuinness and O’Connell, 2008 on unequal wage differentials between public and private sector employees arising from recent wage agreements), inequalities which can only give rise to even greater concerns regarding equitable policy outcomes following the Irish economic downturn.

While some post-liberal theorists focus on renouncing the liberal idea that the parameters of democracy are limited to the boundaries of the nation state (Hirst, 1994, Held, 2006, March and Olsen, 1995), others are concerned with the inclusion of different kinds of political actors and their diverse perspectives (Benhabib, 1996, Fung and Wright, 2003, Mansbridge, 1996, Mouffe, 1996, Young, 2000). Of these, the work of Iris Marion Young is perhaps the most comprehensive and thus, the most useful to our examination of social partnership. In her book, Inclusion and Democracy 
(2000), Young expounds on her theory of democracy in a manner which interweaves the concerns and issues of many post-liberal theorists. She then goes on to set out normatively the conditions under which democracy may be deepened within diverse policy processes.

Drawing from John Rawls' theory that democracy should be measured by its ability to provide just solutions, Young (2000: 27) argues that, since there is no objective common good according to which it is possible to measure whether the outcome of a political process is just or not, justice must be ensured procedurally. Political, or governance processes are thus deemed democratic of 'all significantly affected by the problems and their solutions are included in the discussion and decision-making on the basis of equality and non-domination, and if they interact reasonably and constitute a public where people are accountable to one another' (Young, 2000: 2930). Following this theorisation, Young is interested in the particular context of the inclusion through representation of structurally disadvantaged groups within political society in general. With these concerns in mind, she draws particular attention to two elements of policy processes - communication and representation respectively.

\section{On communication: Diversity and debate}

It is now well established (Rosell, 2004) that participants within more inclusive policy processes which draw in a range of actors and perspectives are likely to come from diverse backgrounds, and are unlikely to have shared sets of myths, assumptions and frameworks of interpretation. In these contexts, where participants are likely to have different levels of what Young terms 'articulateness', Young argues that communication should take place and, indeed, be fostered, in many different forms and at many different levels. Communication norms within policy processes should provide space for participants to relate, share and analyse their experiences as well as to explore possibilities for ameliorating their situation. In this context, Young draws attention to the importance of different forms of speech. According to Young, communication within inclusive fora should include story-telling, protest, the use of pictures/images, and problem-framing as well as problem-solving. Problem-framing, as opposed to problem-solving, involves investigating and interrogating the root causes of identified problems and seeks to address structural and systemic 
inadequacies rather than merely addressing their symptoms. One important communication form identified by Young is that of public debate. Taking up Habermas's ideas on the need for 'public spheres' within societies wherein, he argues, individuals become part of a wider political community through engagement in public discussion and deliberation (Habermas, 1990), Young argues that such public fora serve an important function if they facilitate inclusive processes of communication (2000: 177-178). Taking account of the main criticism of communicative inequality which is often levelled against Habermas ${ }^{3}$, Young argues that public actors (state and civic) have a role in actively fostering communication and debate at this popular level.

\section{On representation: mediating relations}

While the 'Westminster model' (Tansey and Kermode, 1967/8) alluded to by critics of the social partnership process envisages parliament as the sole site of deliberation, decision-making and representation of "the peoples" interests, clearly in Ireland this is no longer the case in practice. Moreover, the failures of an equality of representation are evidenced in the increasing socio-economic inequalities within Irish society (Kirby 2004, NESC, 2005). As we have seen, this issue of equality of representation, as a means of enhancing equality of outcome, is a key feature of democratic systems for Young. She argues that those affected, in particular those heretofore adversely affected, by particular policies be represented within fora deliberating upon and deciding on these policies. Just who does this 'representing', and how they achieve this are key questions. Young argues that representation is not about assuming the identity or substituting for a group of people (the constituents), rather it is about mediating between different actors. She goes on to argue that it follows that any evaluation of a process of representation should examine the nature of the relationship between the representative and the constituents. The representative, though separate from the constituents, should be connected to them in determinate ways. Constituents should also be connected to one another. Young (2000: 128) notes that 'Representative systems sometimes fail to be sufficiently democratic not because the representatives fail to stand for the will of the constituents, but because they have lost connection with them.'

At a time when liberal theories of democracy fall short in assisting our navigation through post-national, increasingly differentiated, and for many, increasingly 
alienated societies, post-liberal democratic theory offers valuable new insights into how democracy within policy processes such as social partnership might be deepened in the dual senses of equality of access and equality of outcome. Drawing particular attention to the two core elements of communication and representation highlighted by Young, the remainder of this article examines Ireland's social partnership in this light, drawing lessons from Malawi's PRSP, and highlighting the key conditions for deepening democracy within Ireland's process.

The analysis presented below draws from both secondary materials and qualitative interviews conducted between 2005 and 2007 with seventy-four state and civil society actors within both Ireland's social partnership and Malawi's PRSP processes. Civil society actors interviewed on social partnership were principally members of the process's Community and Voluntary (CV) pillar, whilst those interviewed on Malawi's PRSP were principally members of the main civil society network involved in the process, the Malawi Economic and Justice Network (MEJN). While both processes also comprise actors from capital and labour (in social partnership these are organised into employer, farmer and trade union pillars), the choice of interviewees for this study reflects the theoretical framework used with, following Young, its explicit focus on the inclusion of marginalised groups in efforts to deepen democracy within and through the respective processes.

\section{Communication within social partnership: Restricting communication within, stifling communication without}

Applying Young's normative framework to social partnership, four principal aspects of communication within the process stand out. The first three relate to communication norms within the process itself, while the fourth highlights how these norms extend outside the process also.

First, within the process the scope of deliberations and debate is considerably restricted with certain issues off the table altogether. For example, issues relating to refugees and asylum seekers and the broader issue of racism, although of particular interest to some members of the CV pillar, are deemed to lie outside the remit of the process. Thus, none of the social partnership strategies make any reference to these 
issues, nor do they appear in the background papers prepared by the National and Economic Social Council (NESC), one of the principal institutions of social partnership. Two members of the CV pillar explain their difficulties in bringing these issues to the process.

There was the whole thing about refugees and asylum seekers, they [state actors coordinating the process] just would not engage in conversation about it, in discussion about it. They said that's not for this agreement [social partnership strategy]. It's not going in there.

(CV pillar member)

Another straw was that close to the end we were trying to raise issues of racism and we were told [by state actors] that racism is not discussed in social partnership.

(CV pillar member)

Second, in contrast to Young's exhortations to engage multiple forms of communication owing to the multiple levels of 'articulateness' of participants, communication norms within social partnership are highly extremely narrow. Policy discourses are privileged, with 'problem-solving' rather than 'problem-framing' the dominant norm. Thus the emphasis is on addressing problems as they stand without addressing or investigating their root structural causes. As a key state official within the process puts it:

I take the view that the social partners have actually a major role to play in both identifying and solving some of the major challenges that face us as a country.

(State official)

This 'problem solving' discourse has been adopted by social partners themselves, as reflected in their own characterisations of the process below:

I think the nugget of partnership is problem-solving.

(Union pillar member)

Social Partnership is, as they [state actors] put it, a problem-solving process. If it stops being that, or if we get the problem solved, we don't have to be bothered about Social Partnership in a sense.

(CV pillar member) 
However, as one representative from the CV pillar explains in relation to both the issues of care more broadly and childcare more particularly, the root causes of the problems remain unexplored.

If you actually look at how they [NESC officials] identify the problem, it's so narrow... We're again back to, back to services, lack of places. That's not the problem in relation to care. You've got an unsustainable situation in relation to care in Ireland and the fact that the state has predominantly seen the whole issue of care as being the private responsibility of families and, within that, women... And the exact same thing is happening in relation to childcare. And until we can shift that ground we're not going to get the type of system and the type of supports that people need.

(CV pillar member)

Wider communicative or behavioural norms as advocated by Young (2000) are also actively eschewed, by state and civil society partners alike, as some pillar members learned as they attempted to build awareness of, and support for particular issues employing less 'professional' methods of communication. In 2003, attempting to raise awareness on emerging issues around policies towards minorities (immigrants and Travellers specifically), a section of the CV pillar staged a walk-out of a formal plenary session in Dublin Castle. One of the group recounts the reaction.

The trade unions in particular were extremely annoyed that we had done this. And also so were the Department of an Taoiseach. Because, and I thought it was very interesting at the meeting, Dermot McCarthy said, 'you can't bring politics into this plenary'. But this is all about politics. So what the hell does that mean?...The other organisations in the [CV] pillar were extremely annoyed that we had done that to them even though they all knew and it wasn't like we were surprising them.

(CV pillar member)

Third, as already evidenced in the quotation above raising shortcomings in the problem-solving discourse around care and childcare, social partnership is highly gendered. Phrases like 'hard nosed', 'hard ball' and 'being business-like' are used to describe attitudes and behaviour within the negotiations. Indeed, women are certainly in the minority within all the institutions of social partnership. In the words of one participant, '...it's the big boys, and it's the big, and the boys'. A number of CV pillar members point to the 'machismo' that pervades the negotiations, with participants expected to work extremely long hours and attend meetings late into the night 
although many note that this is unnecessary as they spend most of their time waiting to meet with state actors and 'just sitting about twiddling our thumbs'. A number of ex-social partners noted in interview that, with family commitments at home, they simply could not participate in the process any more. This gender bias is also manifest in both the communication norms imbuing the process, characterised by one social partner as 'hard-nosed negotiations that suit the unions', and the manner in which certain discourses are ignored. A member of the CV pillar describes the frustration of attempting to raise a debate on the issue of patriarchy within NESC.

Now I mean I do think particularly in NESC it was an extreme, well I suppose lots of places are, but it seemed like really, really difficult around gender inequality, and around women's inequality, and the issue of patriarchy, and how did that actually affect policy outcomes. It just really, a really difficult place for that... there was no real analysis around-you know - how is inequality caused? What are the structural barriers there to prevent it?

(CV pillar representative)

These restrictions on communications extend beyond the walls of the Department of An Taoiseach also however to its impact on public debate and deliberation more broadly. A fourth issue in relation to communication norms in social partnership which has become increasingly apparent in recent years - ironically, by its absence rather than presence - is the reduced level of public debate surrounding the broader developmental policy aspects of the process, together with the virtual invisibility of $\mathrm{CV}$ pillar members in the process. Although the process received some attention in its earlier years, with the CV pillar employing the media to raise public debate in the late 1990s and early 2000s, the dearth of coverage of the CV pillar's contributions during and beyond the 2006 talks stands in marked contrast to these earlier years. An issue of confidentiality surrounds more recent developments in social partnership. As a key state official of the process notes, 'I suppose we would also expect... a degree of observance of the no surprises principle'. This has clearly been communicated in subtle ways to CV pillar members.

There's definitely a confidentiality anyway and I suppose you have to monitor that reasonably as well, there's probably a level of discretion. But there's also a spirit of the agreement or a spirit of social partnership which says ... we'd rather you talk to us than go public. Or they [state officials] may not say it but you'll know it from body language, people not returning your calls, people being snotty. 
(CV pillar member)

The work of the NESF, the NESC and the process's various working committees remains virtually unknown publicly, while the final negotiations themselves are also shrouded in secrecy. The CV pillar in the 2006 negotiation did not adopt a media strategy, although members stressed that all were free to issue statements or carry out interviews as they saw fit. It is noteworthy that, when questioned in 2007 about their lack of media work, a number of members of the CV pillar had come to see the media in terms of a lobbying tool, almost as a last resort, rather than as an instrument to mobilise popular debate. Some noted that they needed to be very careful in employing it in that their interests could suffer as a result.

To be honest it has happened before where something leaked... the government might be willing to make a move on something... and it was leaked to the media and the officials. Suddenly the Minister reads the paper... so you have to be careful in the sense that you could actually damage your own interests... we would use the media judiciously... you want to be very careful.

And again another pillar member

(CV pillar member)

...you need to be careful not to use it [the media] too often. One, you upset the other organisations in the negotiations if you don't manage it right. Two you upset the civil servants.... You need to be careful.

(CV pillar member)

Yet commentators note that this lack of public debate on key issues has silenced dissent with one ex-CV pillar member noting that 'you don't get the crises because they're negotiated away'. And so, while it is generally agreed among all participants that to get movement on something it must be perceived as a 'crisis', the lack of public debate on core issues mutes the elevation of any to the necessary level whereby it may be deemed as such.

Applying Young's theoretical framework therefore, with particular reference to her work in the key area of communication, norms for communications both within and without social partnership clearly limit its scope for deepening democracy. It is noteworthy that while critics of the process (see for example Allen, 2000, Meade and O’Donovan, 2002, Meade, 2005, Murphy 2002) focus on the state as the principal orchestrator and agent of these limitations, the evidence presented here shows how 
these norms have been internalised and are being actively promoted by civil society actors also. These actions of civic actors lead us on to the second core element of democratic processes highlighted by Young - that of representation.

\section{Matridashka dolls and minimised mediation: Representation within social partnership}

As we have seen, while charges of social partnership's inherently 'undemocratic' nature focus on the apparent side-lining of elected leaders, post-liberal theorists, embracing the contemporary reality of the ongoing existence and functioning of broader-based policy networks, focus on the forms of mediation between representatives and their constituents at all levels. Although a common understanding of social partnership (in so far as there is any common understanding given the paucity of public debate on the process), as with other policy networks, is of all social partners sitting down at a table to negotiate together, the reality is actually very different. Comprising a complex labyrinth of multiple institutions and fora, social partnership, for the most part, works on a unilateral (pillar members talking to each other) or bilateral (pillar to state discussions) basis. With the exception of the NESC forum, which offers hotly contested places to only five representatives from each pillar, and occasional formalised plenary meetings, social partners rarely meet with other pillar members, instead spending most of their time talking with members of their own pillar as they attempt to produce joint proposals and inputs as required by the communicative norms of the process. As a result, the majority of many social partners' time is taken up in meetings with other groups within their own pillar rather than with other actors within the wider process. For members of the CV pillar, many of whom were, up until 2003, members of the Community Platform also, this has entailed an endless round of meeting after meeting - a virtual 'Matridashka doll' of meetings, as one participant describes it.

I have to say when I look back at the work we did in the Platform, the amount of time that we spent working within that space within a broader, then housed within another Matridashka doll called the community and voluntary pillar that was in another doll called social partnership, it was just incredibly labour intensive.

(Community Platform member) 
Another CV pillar member describes the complexity of the bureaucracy;

As a new person coming in I used to go to the pillar... my first induction weeks, I went to a pillar meeting and a Platform meeting. I couldn't tell the difference - where one meeting ended-where another began. I didn't know what they were about - hadn't a clue. I used to find it so bizarre that people were just in it, and it was just like a bureaucracy, and that we were part of that bureaucracy really.

(Community Platform member)

While a number of organisations divide the work involved between two or more people, the average estimate of human resource requirements for the process is at least one person full-time, with this intensifying during the period of the negotiations. Unsurprisingly these requirements exclude many groups from the process, in particular smaller groups with limited policy expertise.

To be involved you need to be a national organisation, you need to have some sort of resources. Now that itself a lot of the sector wouldn't have. And even for ourselves, just to have the time and energy to devote to it is huge in a way. And almost too you'd need to be specialised in all of the [policy] areas and not just your own because you're involved in it at every level... It would be hard to see how all community groups on the ground could engage at that level with a process like this.

(CV pillar member)

With such a heavy demand on limited resources, mediation with constituents has to have suffered. This is acknowledged by a number of $\mathrm{CV}$ pillar members, some of whom, following their expulsion from the process (voluntary or otherwise depending on who you talk to. A number of member organisations of the $\mathrm{CV}$ pillar who refused to sign up to the 2003 strategy, Sustaining Progress, subsequently lost their 'Social Partner' status and were thereafter excluded from a range of policy fora associated (either directly or indirectly) with social partnership.), note that their disengagement, from 2003 to 2007, afforded them more time to liaise and reconnect with their membership. With the exigencies of the process' interminable series of meetings exacting a high toll in human resource terms therefore, democracy suffers as representatives' connection to their constituents is eroded.

So is social partnership, as its detractors contend, 'undemocratic'? From the evidence presented above and viewed from a post-liberal democratic stance, the process still fuels such charges. Discourses remain limited; the strict focus on problem-solving 
rather than problem-framing forecloses possibilities for structural debates, with problem-solving addressing symptoms rather than root causes; the restrictive and highly gendered norms of behaviour further limit more diverse modes of participation; the norms of confidentiality imbuing the process mute public debate and participation in developmental debates more broadly; while the institutional exigencies of the process exact a toll on participants' connection with their constituents. The prognosis does not seem good. Yet social partnership, in one form or other, will be with us for the foreseeable future. A key question for practitioners and scholars genuinely interested in democratising governance in Ireland therefore is how social partnership, or any potential successor(s), may be rendered more democratic. Malawi's experiences with a similar process, the PRSP, offer us some lessons in this regard.

\section{Deepening democracy within social partnership: Lessons from Malawi}

Malawi's PRSP was chosen as one from which lessons might be drawn for Ireland's social partnership process for a number of reasons. First, as noted previously, it bears many institutional similarities to social partnership; second, it was one of the first of over seventy such processes to get off the ground and so provides a number of years' experience to draw from; and third, the principal civil society network involved in the process, MEJN, has attracted a significant degree of interest for its energy and activism within the international development community. As well as bearing many institutional similarities to social partnership, communication norms within Malawi's process display a remarkable similarity to those imbuing social partnership.

Discourses remain limited to technocratic, problem-solving exercises, communication norms within the process are restricted, and more critical voices have been excluded from the process.

However, there is one key difference between Malawi's process and that in Ireland. The norms of confidentiality imbuing social partnership, which mute public debate on both the process itself and the actions of its actors, are notably absent from Malawi's process. In contrast, Malawi's PRSP, in particular during its early years, was widely publicised by MEJN, through both the national media, and also through MEJN's 
publication of popular materials such as a simplified version of the 2002-2005 strategy which was produced in several local languages and distributed to groups and associations throughout the country. As a result of these actions the process has stimulated a high level of public debate on both the content of the strategy itself - i.e. the country's developmental options - and the actions of participants within it. As we will see, this stimulation of public debate, a key element of post-liberal democracy as highlighted by Young (2000) and other theorists, has increased the democratic potential of the process, by forcing MEJN to further open the political space afforded through the process and mediate more directly the voices, analyses and aspirations of its constituency. Precisely how this occurred is outlined below.

\section{Democratising governance, democratising political actors: The implications of enhanced public debate in Malawi}

Initially a platform of 27 Malawian NGOs and religious groups, MEJN was formed in 2000 with the express purpose of securing broad-based participation in the PRSP. Throughout the process MEJN systematically employed the media as a tool to increase public awareness on both the existence and nature of the PRSP, and its content. Thus MEJN focused a public spotlight on the process, its content, and its own engagement within it, thereby stimulating public debate and opening the country's political space. Over time, this came to prove something of an Achilles heel for the network however, as global critical debates on NGO legitimacy (see for example Hulme and Edwards, 1997, Pearce, 2000, Lewis and Opoku-Mensah, 2006) combined with popular debate at a national level to bring MEJN's agency within the process, in particular its effectiveness in mediating the interests and perspectives of its membership, under critical scrutiny.

MEJN's initial journey within Malawi's PRSP resembles that of many members of Ireland's CV pillar. While MEJN began with the intention of bringing more actors in - effectively deepening democracy within the process, very quickly network leaders adopted the process' dominant communicative norms. Sourcing technical experts and acquiring a more professional edge, MEJN leaders began to sideline less capacitated (as they saw it) organisations. This increasing control by the network's leadership in 
turn led to conflict within the network where members, feeling excluded and sidelined, accused leaders of becoming turning the network into an NGO in its own right. In the words of one network member;

MEJN is a network. They [network leaders] should not be implementers. Let them use their members... Of course there have been some clashes between MEJN and their members... And people have moved away from getting interested in MEJN. Because MEJN wants to be the implementer. ... I think that's a conflict, that's where the conflict comes in now. So let them identify what is their role. Are they facilitators or implementers? MEJN is not an NGO. The way I understand it, it is a network.

(Representative of MEJN member organisation)

This conflict, following MEJN's publicity work, found its way into public debate more broadly whereupon MEJN's leaders began to find themselves confronted with charges of illegitimacy. From their early days of relying on the World Bank's Voices of the Poor (Naryan et al, 2000) as a basis for its inputs to the PRSP, MEJN leaders were faced with a growing public consciousness that the network had not consolidated a grassroots base which might feed into policy and advocacy activities, thereby putting into practice the theory of 'participatory economic governance' (MEJN, 2004) that the network espoused and informing its representation. Indeed, with an office and entire staff in Lilongwe, MEJN appeared the very embodiment of the 'elite' NGO divorced from its roots, as depicted in the critical development literature of the late 1990s (for example, Hulme and Edwards, 1997, Pearce, 2000). In 2002, cognisant of these issues, responding to public critiques, and seeking to consolidate a grassroots base, MEJN began to build a local network of representation in the form of what became known as the District Chapter Programme.

MEJN's District Chapter Programme consists of locally elected voluntary committees of eight to ten people claiming to represent the interests of their communities at district level. Committees have been established in twenty-seven of Malawi's twentynine districts ${ }^{4}$. While the initiative for the Chapter Programme came from MEJN leaders, committees were elected locally and consist principally of representatives of both local NGOs and local community-based associations including youth groups, women's groups, faith-based groups, and trade and business associations. Responding to public critiques on its legitimacy to represent 'the poor', MEJN leaders' aim in developing the District Chapter structure was to institutionalise a national structure of 
representation which would enable leaders to bring people's issues from the ground to the national policy arena. In MEJN's view, this was to be achieved by Chapter committee members systematically gathering data and information in specified areas (food security, health, education etc.) and feeding this upwards to network leaders for what MEJN terms its 'evidence based advocacy' (MEJN, 2004). Interestingly however, Chapter members have a very different vision for their work. In interviews, committee members in eight different districts all emphasised that they were interested in representing their local communities, bringing issues of local concern and interest to local government structures. In particular, members were interested in moving beyond the main town within the district (where many committee members live) and going out to villages and settlements in outlying areas. Drawing on MEJN's own popularisation of issues of participation and democracy, members were emphatic that MEJN's role lay in facilitating people at the grassroots to articulate their views and concerns. As one Chapter member put it... 'MEJN is for the people... If MEJN is only for the boma [district main town] then we are a failure. It's the people in the grassroots who need MEJN more.'. There is, therefore, clearly a divergence of views on the role and function of local committee structures, together with understandings as to what constitutes representation. While for MEJN leaders, having internalised dominant forms of communication, this representative structure is there to collect 'evidence', i.e. carry out research on specific areas in the 'evidence-based advocacy' which dominates communication norms in both Malawi and Ireland's processes, committee members, employing more popular forms of communication and drawing on MEJN's early work popularising the PRSP and its participative norms, appear to view their role as a portal for the views and perspectives of local communities (however these may be defined or identified) to be fed upward to key decision makers, both through their own Chapter committee representatives at district level, and through those of MEJN's leaders at a national level.

MEJN's experiences serve to demonstrate a fundamental contradiction between the dominant communicative norms favoured within both processes and the requirements of democratic representation as theorised by Young (2000). While MEJN struggles to maintain its status within the PRSP process, in itself a crucial portal to national policy fora more broadly, its locally based membership still lies waiting in the wings, with members of some District Chapter committees becoming increasingly vocal about 
network leaders' support in their efforts towards more perspective-based representation at both local and national level. It remains to be seen how MEJN's leadership will negotiate the conflicting normative demands of state and donors, on the one hand, and Chapter members and their 'communities' on the other. Bridging these relations and poised with one foot in, and one foot out of the hegemonic order, MEJN's future decisions and actions could prove both insightful and inspirational to CV pillar members in Ireland caught in a similar nexus.

\section{Conclusion}

So what lessons can be drawn from Malawi's PRSP which can help deepen democracy within Ireland's social partnership where, as we have seen, the institutional and communicative exigencies of the process hamper the ability of social partners to connect with and meaningfully represent the interests of their constituents and where, perhaps even more significantly, the muting of public debate on the process, its content, and the actions of its actors significantly erodes the democratic potential of the process? MEJN's experience in a process with similar communicative norms shows the challenges in bridging relations inside and outside the process. It also however shows that, if democracy is to be deepened within and through the process, these communicative norms need to be widened. Most significantly, the key driver in deepening democracy within Malawi's process is the network's membership on the ground. Spurred on by the actions of MEJN's leaders in popularising the process, the key lesson we learn from the Malawian experience is that, under conditions of vibrant public debate and genuine perspective-based representation, as witnessed in glimpses in the Malawian case, partnership processes do offer the potential to deepen democracy. Contrarily, under conditions of muted public debate engendered by norms of confidentiality such as those imbuing Ireland's Social Partnership, democracy is indeed diluted.

Are these lessons applicable to Ireland however? While some argue that the CV pillar holds significantly less power than NGOs within PRSP processes, the Irish state's palpable anger at the Community Platform and the National Women Council's rejection of the 2003 social partnership strategy, with its implicit exposure of dissensus, suggests otherwise and demonstrates the strong legitimising power of $\mathrm{CV}$ 
pillar members within the process. While, following their rejection of the 2003 strategy, core state funding to the principal organisation behind the Community Platform, the Community Worker's Cooperative, was cut, funding to a number of non-dissenting CV pillar members was increased (Data received by email communication from the Department of Community and Family Affairs). Moreover, financial inducement, in the form of the 'Social Partnership Scheme', introduced in 2007 and committing 10 million Euro per annum to CV pillar members (Government of Ireland, 2006), has proven successful in attracting dissenting partners back into the process. Claims of consensus, partnership and inclusion clearly ring hollow when participants dissent. CV pillar members therefore, like MEJN, possess significant legitimising power. The challenge is for members to recognise this power, and to strategically harness and use it in deepening democracy within the process. 


\section{Bibliography}

Allen, Kieran (2000) The Celtic Tiger - The Myth of Social Partnership in Ireland (Manchester: Manchester University Press)

Bang, Henrik P (2003) Governance as Social and Political Communication (Manchester: Manchester University Press)

Benhabib, Seyla (1996) The Democratic Moment and the Problem of Difference, in Seyla Benhabib (editor), Democracy and Difference: Contesting the Boundaries of the Political, pp. 3-18 (New Jersey: Princeton University Press)

Berlin, Isaiah (1991) Two concepts of liberty, in David Miller (editor), Liberty, pp. 33-57

(Oxford: Oxford University Press)

Bobbio, Norberto (1987) The Future of Democracy (Cambridge: Polity Press)

Bogason, Peter and Juliet Musso (2006) The Democratic Prospects of Network Governance, American Review of Public Administration, 36(1), pp. 3-18

Castells, Manuel (2004) The Power of Identity, (second edition) (Oxford: Blackwell)

Cornwall, Andrea and Karen Brock (2005) What do Buzzwords do for Development Policy?

A Critical look at 'participation', 'empowerment' and 'poverty reduction', Third World Quarterly, 26(7), pp. 1043-1060

Dean, Mitchell (2007) Governing Societies (Berkshire, UK: McGrawHill / Open University Press)

FineGael (http://www.finegael.ie/news/documents/NEWDEPARTURE\%20FGLAB\%20D OC1.pdf, accessed September $\left.5^{\text {th }}, 2008\right)$

Fung, Archon and Erik Olin Wright (2003) Thinking about Empowered Participatory Governance, in Archon Fung and Erik Olin Wright, Deepening Democracy: Institutional Innovations in Empowered Participatory Governance, Verso, www.ssc.wisc.edu/ wright/Deepening.pdf, accessed August $28^{\text {th }}, 2003$

Government of Ireland (2006) Towards 2016: Ten Year Framework Social Partnership Agreement (Dublin: Government Publications)

Habermas, Jurgen (1990) Moral Consciousness and Communicative Action, trans. C.

Lenhardt and S. Weber Nicholson (Cambridge, MA: MIT Press)

Hastings, Tim, Brian Sheehan and Padraig Yeates (2007) Saving the Future: How Social Partnership Shaped Ireland's Economic Success (Dublin: IRN Publishing)

Held, David and Anthony McGrew (2003) The Global Transformations Reader (UK: Polity Press) 
Held, David (2006) Models of Democracy (UK: Polity Press)

Hirst, Paul (1994) Associative democracy: New forms of economic and social governance (Cambridge, MA: Polity Press)

Hulme, David and Michael Edwards (1997) NGOs, States and Donors: An Overview, in NGOs, States and Donors - Too Close for Comfort? (New York: Save the Children Fund)

IMF / World Bank (2002) Review of the poverty reduction strategy paper approach: early experience with interim PRSPs and full PRSPs, IMF / World Bank, http://siteresources.worldbank.org/INTPRS1/Resources/3836061092340662634/earlyexp.pdf, accessed August 15 $5^{\text {th }}, 2004$

Kelly, Eilish, Seamus McGuinness and Philip O’Connell (2008) Benchmarking, Social Partnership and Higher Remuneration: Wage Setting Institutions and the Public Private Sector Wage Gap in Ireland, Working Paper No. 270, (Dublin: ESRI)

Kirby, Peadar (2004) Development Theory and the Celtic Tiger, European Journal of Development Research, 16(2), pp. 301-329

Kooiman, Jan (2003) Governing as Governance (London: Sage Publications)

Lewis, David and Paul Opoku-Mensah (2006) Moving forward Research Agendas on International NGOs: Theory, Agency and Context, Journal of International Development, 18(5), pp. 665-675

Macpherson, Crawford Brough (1977) Life and Times of Liberal Democracy (Oxford: Oxford University Press)

Manin, Bernard (1997) The Principles of Representative Government (Cambridge: Cambridge University Press)

Mansbridge, Jane (1996) Using the power/fighting power: The polity, in Seyla Benhabib (editor), Democracy and Difference: Contesting the Boundaries of the Political, pp. 46-67 (New Jersey: Princeton University Press)

March, James G and Johan P Olsen (1995) Democratic governance (New York: The Free Press)

Meade, Rosie and Orla O’Donovan (2002) Editorial Introduction: Corporatism and the ongoing debate about the relation between the state and community development, Community Development Journal, 37(1), pp. 1-9

Meade, Rosie (2005) We hate it here, please let us stay! Irish social partnership and the community/voluntary sector's conflicted experiences of recognition, Critical Social Policy, 25(3), pp. 349-373 
MEJN (2004) MEJN Programme Support Document (Malawi: MEJN)

Mouffe, Chantal (1996) Democracy, Power and the Political, in Seyla Benhabib (editor),

Democracy and Difference (New Jersey: Princeton University Press)

Murphy, Gary and John Hogan (2008) Fianna Fáil, the Trade Union Movement and the

Politics of Macroeconomic Crises, 1970-82, Irish Political Studies, 23(4), pp. 577598

Murphy, Mary (2002) Social partnership - is it 'the only game in town'?, Community

Development Journal, 37(1), pp. 80-90

Narayan, Deepa with Raj Patel, Kai Schafft, Anne Rodemacher, and Sarah Kock-Schulte (2000) Voices of the Poor: Can Anyone Hear Us? (Washington/Oxford: World Bank/ Oxford University Press)

NESC, National Economic and Social Council (2005) The Developmental Welfare State, Report No 113 (Dublin: NESC)

Newman, Janet (2005) Participative Governance and the Making of the Public Sphere, in Janet Newman (editor), Remaking Governance: Peoples, Politics and the Public Sphere (UK: The Polity Press)

Ó Cinnéide, Séamus (1999) Democracy and the Constitution, Administration, 46(4), pp. 4158

Ó Cinnéide, Séamus (2006) Partnership talks need democratic accountability, The Irish Times, 04/04/2006

Pearce, Jenny (2000) Development, NGOs and civil society: the debate and its future, in Deborah Eade (editor), Development, NGOs and Civil Society, pp.15-43 (Oxford: Development in Practice Reader)

Pierre, John (2000) Debating governance: Authority, steering and democracy (London: St Martin's Press)

Reddel, Tim (2004) Third Way Social Governance: Where is the State?, Australian Journal of Social Issues, 39(2), pp. 129-143

Rosell, Steven A (2004) A Missing Step in the Governance Process, Development, 37(4), pp. 43-49

Sorenson, Eva and Jacob Torfing (2005) Network Governance and Post-Liberal Democracy, Administrative Theory and Praxis, 27(2), pp. 197-237

Tansey, Stephen D and David G Kermode (1967/8) The Westminster Model in Nigeria, Parliamentary Affairs, 19, (37)

The Irish Times (2007) Partnership process is 'undemocratic', The Irish Times, 28/06/2007 
Triantafillou, Peter (2004) Addressing network governance through the concepts of governmentality and normalisation, Administrative Theory and Praxis, 26(4), pp. 489509

Weber, Heliose (2006) A Political Analysis of the PRSP Initiative: Social Struggles and the Organisation of Persistent Relations of Inequality, Globalizations, 3(2), pp. 187-206 Young, Iris Marion (2000) Inclusion and Democracy (Oxford: Oxford University Press) 


\footnotetext{
${ }^{1}$ Originally introduced by the World Bank and International Monetary Fund in 1999 as a condition of debt relief under the Highly Indebted Poor Country Initiative (HIPC), the elaboration and implementation of PRSP national development programmes are now a condition of all World Bank and IMF funding.

${ }^{2}$ Aggregative theories of democracy define equality in terms of equal access to political channels of influence and view regular elections, open and uncensored public debate, and transparency within the policy process as key in this, while integrative theories define equality in terms of the influence citizens possess in concrete decision-making processes, thereby focusing on political empowerment (for a fuller discussion of these two strands within liberal democratic theory see Berlin, 1991).

${ }^{3}$ Habermas's contributions in this area have been criticised in the respect that they appear to assume all actors are able to participate equally and ignore issues of differential power and capacity.

${ }^{4}$ Malawi had twenty-eight districts. One of these was recently split into two to make twenty-nine.

MEJN has set up Chapters in all except the districts of N'neno and Likoma.
} 